\title{
Discurso(s) sobre o ensino de língua materna em um curso de formação de professores
}

\author{
Discourse(s) about the teaching of mother \\ language in a language teacher education \\ course
}

Cristiane Carvalho de Paula Brito*

Universidade Federal de Uberlândia - UFU ${ }^{1}$

Uberlândia - Minas Gerais / Brasil

\begin{abstract}
RESUMO: Este artigo visa analisar, com base no embate de vozes, as imagens que professores de língua(s) em formação constroem em seu discurso, em relação à gramática e ao ensino de língua materna. Fundamentamo-nos na Análise do Discurso de linha francesa e partimos da hipótese de que o discurso dos sujeitos da pesquisa é constituído por vozes conflitantes, sustentadas por diferentes filiações discursivas, e de que os sujeitos consolidam, independentemente do ano em que estão no curso, concepções homogeneizantes e totalizadoras sobre a língua materna e seu ensino.
\end{abstract}

PALAVRAS-CHAVE: língua materna, formação de professores, gramática, imagens, análise do discurso.

ABSTRACT: This article aims to analyze, taking the clash of voices into account, the images that pre-service language(s) teachers build in their discourse, concerning grammar and the teaching of their mother language. We are anchored in the theoretical framework of the French Discourse Analysis and we assume that the discourse of our subjects of research is made up of conflicting voices from different discursive filiations, and that the subjects consolidate, regardless of the year in which they are in their course, homogeneous conceptions about the mother language and its teaching.

KEYWORDS: mother language, teacher education, grammar, images, French discourse analysis.

\footnotetext{
* carvalhodepaula@yahoo.com

${ }^{1}$ As reflexóes deste artigo fazem parte da pesquisa que desenvolvemos em nossa tese de doutoramento, sob a orientação da Profa. Dra. Maria Augusta Bastos de Mattos, no Programa de Línguística Aplicada, na Universidade Estadual de Campinas.
} 


\section{Introdução}

Um dos questionamentos comuns a professores pré-serviço diz respeito à forma como podem (ou devem), no ambiente de uma sala de aula, trabalhar seu objeto de ensino. Aliás, diríamos que os questionamentos recaem, mais especificamente, em torno da necessidade de elaboração de um objeto de ensino a partir de um objeto de estudo.

Em que consiste o ensino de língua materna? Qual o papel de um professor de língua portuguesa? Qual o lugar da gramática dentro da sala de aula? Essas são algumas das perguntas que interpelam professores (e futuros professores) de língua materna e que nos propomos a discutir, neste trabalho, a partir da análise das imagens de gramática e de ensino de língua materna consolidadas (ou refutadas) no discurso de sujeitos professores-de-língua(s)em-formação, termo esse que aqui utilizaremos para designar a posição discursiva ocupada por sujeitos que estão cursando um curso de Licenciatura em Letras.

Cremos que é no e pelo discurso que os objetos vão se construindo, que saberes vão (ou não) se legitimando e se tornando práticas de ensino / aprendizagem, práticas de linguagem e práticas sociais. Dessa forma, não há instância melhor que o discurso - lugar em que o indivíduo, interpelado pela ideologia, se constitui como sujeito, ao se filiar a uma certa memória discursiva - para nos permitir investigar os aspectos relevantes dessa formação.

Ancorados na Análise do Discurso de linha francesa, partimos da hipótese de que o discurso dos sujeitos da pesquisa é constituído por vozes conflitantes e contraditórias que são, por sua vez, sustentadas por diferentes filiaçōes discursivas. Ao tomar a palavra para discorrer sobre o seu objeto de estudo, os sujeitos tecem, no fio linear do discurso, uma aparente unidade de sentidos, de saberes - que pode ser questionada, ao se analisar os sentidos verticais que atravessam as formulações linguísticas.

Aventamos ainda a hipótese de que, apesar de serem (ou terem sido) expostos a diferentes discursos sobre a língua / linguagem, sobre o processo de ensino / aprendizagem, sobre o sujeito etc., os sujeitos da pesquisa consolidam, independentemente do ano em que estão no curso, concepções homogeneizantes e totalizadoras sobre a língua materna e seu ensino.

Dessa forma, nosso gesto de leitura em relação ao corpus caminha no sentido de analisar as vozes em embate, as posições discursivas em confronto, as fissuras que inevitavelmente marcam a tomada mesma da palavra. 


\section{(Des)tecendo os fios}

Para que pudéssemos destecer alguns fios no discurso dos professoresem-formação, apoiamo-nos no arcabouço teórico da Análise do Discurso (AD) de linha francesa, por meio de autores como Pêcheux (1997a, 1997b, 1997c) e Orlandi (2004, 2005a, 2005b, 2005c), e partimos da compreensão de que o sujeito, perpassado pelo inconsciente, se constitui na e pela linguagem, irremediavelmente afetado pelo simbólico.

Interpelado pela ideologia, o indivíduo se constitui como sujeito ao se identificar com certas formaçôes discursivas (FDs), e, portanto, significar-se. Em relação ao conceito de formação discursiva, convém dizer que ele se refere a "aquilo que, numa formação ideológica dada, isto é, a partir de uma posição dada numa conjuntura dada, determinada pelo estado da luta de classes, determina o que pode e deve ser dito (articulado sob a forma de uma arenga, de um sermão, de um panfleto, de uma exposição, de um programa, etc)" (PÊCHEUX, 1997a, p. 160). Pêcheux chama a atenção para a natureza heterogênea da FD, ressaltando que ela não é um espaço estrutural fechado, mas constitutivamente invadida por outras FDs. É uma "unidade dividida", cujas fronteiras se deslocam continuamente (ORLANDI, 2001a, p. 109).

O conceito de FD nos permite compreender a relação de interioridadeexterioridade que constitui o trabalho da linguagem. Assim, o sujeito não pode encontrar-se fora da FD que o domina e é nela que ele adquire a sua identidade, já que é nela que as palavras ganham sentido.

Quanto ao conceito de discurso propriamente dito, pode-se afirmar que ele é entendido como efeito de sentidos entre locutores (PÊCHEUX, 1997a). Efeito justamente porque, ao se refutar as "transparências" (do sujeito, da linguagem, da história, da "realidade"), o que resta ao sujeito são efeitos (de objetividade, de transparência, de comunicação bem-sucedida...).

Além disso, o discurso se constitui na articulação do intra e interdiscurso. O primeiro diz respeito ao fio linear, horizontal do dizer - trata-se do funcionamento do discurso com relação a si mesmo, isto é, a relação entre o que eu digo agora, o que eu disse antes e o que eu direi depois. Já o interdiscurso é concebido como a dimensão vertical do dizer. Em outras palavras, é aquilo que fala sempre "antes, em outro lugar e independentemente", isto é, a memória do dizer (PECHEUX, 1997a, p. 163).

Dessa forma, entendemos que os discursos têm sentido à medida que se relacionam com outros discursos, com dizeres anteriores, com esta ou aquela memória discursiva. O discurso é, pois, marcado pela alteridade, isto é, por sua exterioridade e historicidade constitutivas. 
Finalmente, deve-se ressaltar que, sendo o sujeito cindido e fragmentado, interessa-nos investigar, em seu discurso, não o seu conteúdo, mas a posição que o sujeito ocupa ao tomar a palavra, posição esta determinada pelas condiçôes de produção do próprio discurso, afetadas pelas formações discursivas em que se encontra o sujeito. Em outras palavras, o que interessa à $\mathrm{AD}$ não é o indivíduo empírico, mas o sujeito discursivo que, interpelado pela ideologia, é capaz de produzir sentidos, de se significar, enfim, de se constituir mesmo como sujeito. Portanto, o discurso que analisamos interessa-nos por ser assumido por um sujeito que está na posição de professor-de-língua(s)-em-formação.

\section{A "falta" da maldita gramática}

Em nossa tese de doutorado, analisamos, por meio de um questionário e de produções escritas, os dizeres de alunos, em diferentes momentos do curso de Letras, em relação ao saber sobre a língua materna.

Uma leitura inicial das respostas nos permitiu constatar que o discurso dos sujeitos acerca da língua materna estabelece uma relação de confronto com a gramática normativa $(\mathrm{GN})$, marca da tensão entre saberes oriundos de diferentes regiōes interdiscursivas.

Neste trabalho, nos restringiremos a analisar as imagens construídas no discurso de sujeitos professores-de-língua(s)-em-formação em relação à gramática e ao ensino de língua materna, ao responderem às seguintes perguntas do questionário: Você acha que seria interessante se fosse incluida, no curso de Letras, a disciplina "Gramática Normativa"? Justifique a sua resposta; e Qualo papel de um professor de lingua portuguesa?

Nosso gesto de leitura foi no sentido de analisar o embate entre as vozes da posição-sujeito-professor-de-língua(s)-em-formação e a posição-sujeitousuário-da-língua. Concebemos esta como a posição ocupada por um sujeito que, apesar de possuir concepções acerca de um saber metalinguístico, não se especializou no discurso "legitimado", "científico" da linguagem, ao contrário da primeira que se configuraria como um novo lugar de poder / saber do sujeito.

A voz do professor-em-formação leva ao questionamento da posição discursiva do sujeito-usuário-da-língua. Desse modo, o primeiro não pode mais assumir, incondicionalmente, sem ressalvas, os pressupostos que sustenta(va)m a posição desse último.

Em relação à primeira pergunta, é necessário salientar que analisamos apenas as respostas afirmativas, por compreender que elas já se configuram como um embate com o discurso da academia, com o dizer da formação discursiva que defende a não inclusão da disciplina "Gramática Normativa” no curso. 
Nosso corpus se constitui de respostas dos alunos de um curso de Letras, em uma universidade federal no interior de Minas Gerais, a um questionário aplicado por nós, na época de nossa atuação como professora substituta nessa instituição, no período de 2005 a 2007.

Analisaremos alguns recortes discursivos que representam o nosso gesto de leitura em relação ao nosso corpus. Esclarecemos que as respostas foram apresentadas tais como redigidas pelos sujeitos e que a referência colocada ao final de cada resposta diz respeito, respectivamente, ao período cursado pelo sujeito e ao número da determinada resposta, dentre as respostas totais daquele período. ${ }^{2}$ Além disso, sublinhamos nos recortes os trechos que, a nosso ver, indicam mais explicitamente o embate das vozes, no intuito de facilitar a leitura.

Vejamos alguns recortes da pergunta: Você acha que seria interessante se fosse incluida, no curso de Letras, a disciplina "Gramática Normativa"? Justifique a sua resposta. ${ }^{3}$

Acho que devem incluir a Gramática Normativa no curso de Letras. Pois afinal, a maioria das pessoas irá lecionar português, e seria interessante ter pelo menos uns dois periodos sobre Gramática Normativa, pois até hoje é essa que se leciona nos Ensinos Fundamental e Médio. (1 per:64res).

Acredito que sim, para uma melhor forma de ensinar aos alunos pois as formas de ensino não mudaram. (1 per:84res).

Sim. Apesar da "Gramática Normativa" apresentar várias contradiçôes, eu acho necessário que ela seja incluida no curso, pois futuramente seremos professores e temos a necessidade de saber bem sobre todos os tipos de ensino de nossa lingua, principalmente sobre o ensino prescritivo, o que tem sido mais ensinado em nossas escolas. (4per:16res).

Na minha opiniāo, sim, pois a gramática normativa é a que contém a forma culta da língua. Evivemos em uma sociedade totalmente presa a essa forma, onde "falar bem" é até uma questão de sobrevivência, ainda mais para nós que somos futuros professores. (4per:57res).

\footnotetext{
${ }^{2}$ Os períodos referem-se à organização semestral do curso. Na época de nossa pesquisa, o curso se organizava em quatro anos, divididos em oito períodos e o aluno tinha a opção de fazê-lo na parte da manhã ou da noite.

${ }^{3}$ Em relação a esta primeira pergunta, inserida no questionário após a análise parcial de nossos dados, foram coletadas 47 respostas do primeiro período, 63 respostas do quarto período, 10 respostas do sexto período, e 7 respostas do oitavo período.
} 
Acredito que sim. Pelo menos enquanto essa for a principal disciplina cobrada no ensino de Lingua Portuguesa nas escolas do país. O que sinto é que nos preparamos para dar aulas em salas de aula que ainda são idealizadas. (6per:16res).

Sim, afinal de contas, é isso que se ensina nas escolas. Pelo menos alguma noção de Gramática Normativa teríamos, para no mínimo compararmos com as demais gramáticas a que mencionam como sendo a que deve ser dada nas escolas. (6per:21 res).

Acredito que sim, pois seria uma forma de aprendermos mais um pouco do que aprendemos de forma muito rápida, no ensino fundamental e médio, também nos auxiliaria na escrita e na fala, pois às vezes nem parece que somos alunos do curso de letras e que saíremos dali para sermos professores de lingua portuguesa. Pois, infelizmente temos dificuldades de escrever e até mesmo de ler perfeitamente. Outra disciplina que teria de ter pelo menos até a metade do curso ou durante todo o curso é leitura e produção de texto. Acho muito pouco, termos leitura e produção somente por dois periodos, $e$ além disso, a leitura e produção de texto II ser uma mera cópia da I, sem acrescentar nada de conteúdo para nosso conhecimento. (8per:13res).

Podemos perceber que os sujeitos consolidam uma concepção tradicional de ensino de língua materna (e, consequentemente, de professor de português), independentemente do momento em que se encontram no curso de Letras.

Vê-se que o sujeito, ao falar sobre a gramática normativa, se constitui no discurso da falta, já que ele não possuiria a "ferramenta" necessária para ensinar, o que geraria a percepção de uma lacuna entre a teoria e a prática, o sentimento mesmo de que nos preparamos para dar aulas em salas de aula que ainda são idealizadas. ${ }^{4}$

A imagem de gramática como língua legítima se fixa no discurso do sujeito, mesmo que ele confesse que ela apresenta várias contradiçôes ${ }^{5}$ ou ainda que ele entenda que aliar a gramática normativa ao conceito de "falar bem" só o pode, agora, ser feito entre aspas.

Por entender que a gramática é a concretização "perfeita" e "autêntica" da língua (ou talvez a própria língua), o sujeito projeta a imagem que tem de

\footnotetext{
${ }^{4}$ Recorte 6per:16res.

${ }^{5}$ Recorte 4per:16res.

${ }^{6}$ Recorte 4per:57res.
} 
si mesmo e a que o outro tem dele, enquanto professor de português: alguém que deve ter total conhecimento da gramática normativa, caso contrário nem parece que somos alunos do curso de letras e que sairemos dali para sermos professores de lingua portuguesa, ${ }^{7}$ para retomar as palavras de um aluno formando.

Para melhor visualizarmos isso, observemos a resposta abaixo de um sujeito do quarto período:

Um professor de Morfologia ou Sintaxe no curso de Letras muitas vezes aprofunda o conhecimento em torno de teorias propostas a nivel acadêmico e superior e partindo do pressuposto que o aluno já sabe não ensina a Gramática Normativa. Contudo, seria interessante a inclusão dessa disciplina na grade curricular, pois não podemos ignorar a realidade da educação brasileira, o aluno chega ao nivel superior, sobretudo no curso de Letras, sem ter dominio da norma culta e padrão. Acho falho o curso de Letras nesse aspecto, inclusive retomando a nona questão, quando eu digo que faço Letras as pessoas instantaneamente dizem: "Nossa você deve ter um português perfeito, não é mesmo?” pressupondo que estudamos fielmente a Gramática Normativa. Como graduanda do curso considero de extrema importância ter dominio impecável da Gramática Normativa, afinal a partir da nossa licenciatura uma das carreiras que podemos atuar é como professores de Português. (4per:63res).

A gramática, por meio de expressões como português perfeito, domínio impecável, fidelidade, se inscreve no plano do divino, da completude. A voz que o sujeito dessa resposta projeta como sendo a do outro - a dos alunos que chegam ao nivel superior, sobretudo no curso de Letras, sem ter domínio da norma culta e padrão e a das pessoas fora do curso de Letras que o questionam quanto a ter um português perfeito - é também a sua. Trata-se do seu desejo de "dominar" a língua, uma vez que a falta desta questiona o seu próprio lugar como futuro professor de Português.

Contudo, ocupando o espaço da formação discursiva de professor-delíngua(s)-em-formação, o sujeito é interpelado a fazer ressalvas em relação ao seu posicionamento de ser a favor de aulas de gramática normativa no curso superior. Ao menos isso é o que se pode observar no uso do advérbio '(in)felizmente', no recorte abaixo de um sujeito de oitavo período:

\footnotetext{
7 Recorte 8per:13res.
} 
Acho que seria super interessante inserir a disciplina "Gramática Normativa" no curso, principalmente, porque felizmente ou infelizmente nós alunos do curso nada sabemos sobre a mesma, nem mesmo sabemos critica-la por não a conhecer. É feio dizer isso mas é a mais pura verdade. É também a causa da maioria das reclamaçôes dos alunos do curso. Sem contar que os alunos de filosofia fizeram e estão desenvolvendo um projeto de extensão aprovado pela Universidade de aulas de gramática. Muita gente já até me disse que a Letras é que deveria estar fazendo isso, mas ninguém se mobiliza nesse sentido. Também não sei o histórico de decisöes que levou à configuração de nosso curso sem gramática e nem quero criticar isso, só sei que talvez quem sabe os murmúrios de corredor dos que não estudam sozinhos, venha a cessar se de repente for oferecido uma disciplina de gramática normativa. É bem capaz que se for muito rigidamente ministrada por exemplo os murmúrios retornem e ai deve-se pensar bem a respeito do formato avaliativo e teórico a se adotar. (8per:16res)

Diz-se que felizmente nada sabemos sobre a GN porque, afinal, o curso de Letras a questiona, enfatizando que ela não é tão necessária quanto se pensava. Porém também se diz infelizmente porque não se pode criticar a GN sem conhecê-la, ressaltando que é feio dizer isso mas é a mais pura verdade, em que o adjetivo feio pode ser referido tanto ao fato de não se saber a gramática quanto ao de se almejar saber (e não poder confessar isso de uma certa posição discursiva).

A ausência dessa disciplina no curso seria a causa das reclamaçôes dos alunos do curso e dos murmúrios de corredor, e aqui podemos ver como a voz desses outros se con-funde na (com a) voz do sujeito que enuncia, denunciando o seu desejo de se apropriar do saber representado pela gramática.

O sujeito prossegue, mostrando a sua incompreensão diante do fato de que ninguém se mobiliza a oferecer aulas de gramática, em um projeto de extensão, o que teria ficado a cargo do curso de Filosofia, e não do de Letras, como seria de se esperar.

Por fim, a negativa nem quero criticar ao se referir à configuração de nosso curso sem gramática reforça o embate de vozes entre as diferentes posições discursivas. Não se quer criticar por não poder? Por ser feio? De qualquer forma, a crítica está posta.

O jogo - tenso - entre o saber anterior e o saber a que agora é exposto esse sujeito marca o seu discurso de contradições inevitáveis, uma vez que se almeja algo (no caso, o saber representado pela gramática) sem o poder dizer, senão com ressalvas, a fim de não soar feio. 
Tais contradições não podem ser apagadas ou "resolvidas", mas existem como prova de que a transparência da linguagem, dos sujeitos, do aprendizado é somente uma ilusão. Necessária para todos; almejada (pesquisada, discorrida, afirmada) por alguns. Contradição que se pode detectar na resposta abaixo, com a qual encerramos esta seção:

Sim, acho que o principal problema que os alunos de letras tem é que não tiveram uma atenção ou uma preocupação em aprender a gramática normativa nos ensinos fundamental e médio, acho que essa matéria acabaria com uma serie de problemas que, depois, quando os alunos se tornam professores, não conseguem ensinar a maldita da gramática. (1per:55res).

Vê-se que a gramática seria o lugar da completude, capaz de acabar com uma série de problemas relativos ao uso da língua, já que permitiria o alcance do "domínio" da língua. Contudo, ao mesmo tempo em que se a quer dominar, também se diz que ela é maldita, afinal é difícil, é contraditória, é complexa, é mal ensinada, é mal aprendida, enfim, é mal-dita. E o é pelos que, sem sucesso, a desejam dizer, apoderando-se de "todas" as suas regras (como se a totalização não fosse uma construção imaginária), mas também pelos que a maldizem, criticando-a, apontando suas falhas e questionando sua imagem de ser "a" língua portuguesa.

\section{Língua Portuguesa: vilã e companheira}

A pergunta Qual o papel de um professor de Lingua Portuguesa? nos permitiu analisar as imagens construídas pelos sujeitos, não apenas em relação à gramática, mas, mais especificamente, ao ensino da língua materna. ${ }^{8}$

Se, por um lado, como observamos na análise anterior, o aluno legitima o ensino tradicional de língua, que prioriza a gramática normativa e confere a esta uma dimensão de totalidade, por outro, ao discorrer sobre o papel do professor de língua portuguesa, o sujeito, perpassado pelo discurso pedagógico, relativiza o lugar da gramática na escola, enfatizando a necessidade de se contextualizar o seu ensino.

\footnotetext{
${ }^{8}$ Em relação a esta pergunta, foram analisadas 83 respostas do primeiro período, 17 respostas do segundo período, 63 respostas do quarto período, 19 respostas do quinto período, 23 respostas do sexto período, 8 respostas do sétimo período e 16 respostas do oitavo período.
} 
Trata-se, então, do discurso da mudança, tal como denominado por Pietri (2003), surgido com a democratização do ensino e a necessidade de valorização da língua em uso. O autor destaca que as décadas de 60 e 70 do século 20 são marcadas pela democratização do ensino, ou seja, abrem-se as portas das escolas à parte da população menos favorecida e que não tinha acesso às variedades linguísticas prestigiadas. Baseado na teoria da comunicação, $\mathrm{o}$ ensino de português ${ }^{9}$ passa a ter um caráter pragmático e utilitarista, com o objetivo de desenvolver o uso da língua.

Com base no estudo de Soares (2002), Pietri (2003) aponta que a gramática é minimizada nos livros didáticos - e é nesse momento que surge, então, a polêmica quanto ao seu ensino. Além disso, amplia-se o conceito de leitura e valoriza-se a oralidade para a comunicação cotidiana.

Ainda conforme Soares, essa mudança permanece até meados dos anos $80^{10}$ do século 20 , sendo esse momento marcado, principalmente, pela chegada de novas teorias da área das ciências linguísticas ao campo do ensino de língua materna. Esse processo é iniciado na década de 60 do mesmo século com a introdução dessas ciências nos currículos de formação de professores, contudo as teorias relativas ao ensino de língua materna chegam à escola apenas em 1980 .

Dessa forma, o denominado ensino tradicional - baseado em uma variedade única da língua (a escrita literária), por meio da gramática da língua portuguesa, e acusado de discriminação daqueles que, então se tentava "incluir" - não está em plena vigência e, nesse momento, a Linguística enfrenta a necessidade de discutir sua responsabilidade em relação ao ensino, tentando desvencilhar-se da imagem de permissividade que lhe foi atribuída em setores do meio não-acadêmico. ${ }^{11}$ Aliás, Pietri (2003) chama a atenção para a heterogeneidade do termo "ensino tradicional", já que o ensino de português,

\footnotetext{
9 Pietri salienta que a disciplina 'português' passa a ser denominada 'comunicação e expressão' (nas séries fundamentais do ensino), e 'comunicação em língua portuguesa' (nas séries finais do $1^{\circ}$ grau). No $2^{\circ}$ grau, ela é denominada 'língua portuguesa' e 'literatura brasileira'.

${ }^{10}$ A disciplina volta a ser chamada de português com a redemocratização do ensino.

${ }^{11}$ Pietri aponta que essa responsabilidade foi transferida para outras áreas, especialmente para o livro didático, acusado de dar aos textos "um tratamento epistemológico como se funcionassem apenas ao nível literal. O processo do dizer seria visto como linear, transparente e epidérmico, resultando numa 'anestesia interpretativa'" (p. 36).
} 
comumente denominado "tradicional", deve ser concebido como um percurso que sofre mudanças em decorrência de aspectos sociais e econômicos.

Nesse sentido, o discurso da mudança vai afirmar a necessidade de modificar o ensino para atender as camadas da população emergentes à escola; e de considerar e respeitar a linguagem do aluno, levando-o a se apropriar da norma socialmente prestigiada, como se pode conferir nas respostas a seguir:

Mais do que ensinar a gramática o professor de português deve estabelecer um contato entre o aluno e a língua mostrando-a dentro da realidade do aluno. (1 per:3res).

Mostrar textos interessantes, opiniōes críticas e relevantes, a importância mesmo do Português, na vida deles, principalmente quando for escolher uma profissão e um emprego. E aproveitar que na condição de professores de Português podemos utilizar coisas legais que interessem os alunos como músicas, filmes, teatros e trazer isso para acrescentar tanto na área de literatura quanto na gramática (podemos explorar as músicas). (1per:27res).

Ensinar aos alunos as regras gramaticais, mas de maneira lúdica, participativa entre alunos e professor. Aulas áridas dever ser evitadas para não cansar os alunos fazendo-os criar aversāo pela disciplina. (1 per:38res).

O papel de um professor é ensinar o aluno compreender os textos e diálogos, $e \underline{\text { ão }}$ assustar o aluno impondo regras e normas. (1 per:59res).

O papel de um professor de Lingua Portuguesa é estimular e motivar os alunos a terem interesse pela lingua, utilizando métodos pedagógicos apropriados eficazes com o objetivo de que os alunos assimilem o conteúdo de forma prática e agradável. (2per:3res).

O papel do professor é influenciar e ativar no aluno o desejo de aprender a lingua, e não impor a disciplina como um obstáculo que tem que ser superado. Se o professor expõe o Português como algo obrigatório, o aluno perde o gosto, e a vontade de trabalhar de forma livre e desinteressada com a linguagem. (2per:17res).

O papel do professor de Lingua Portuguesa é transmitir aos alunos as regras e normas da "Gramática Normativa", é claro que o professor deve respeitar os conhecimentos prévios de cada aluno e o meio social que o mesmo está inserido. (4per:8res). 
Ensinar a compreensão da língua portuguesa sem impor o que é certo ou errado. (4per:11res).

O papel de um professor pra mim seria despertar o sentido crítico do aluno em relação ao que está sendo ensinado. Ensinando a matéria mais ao mesmo tempo mostrando a significancia de estar aprendendo aquilo, tornado o português algo acessivel ao aluno, trazendo aquilo para dentro da sua realidade. (5per: $11 \mathrm{res})$.

O professor de Lingua Portuguesa deve conscientizar seus alunos da importância de saber o uso correto da Lingua. Levar o idioma para o diaa-dia do aluno e despertar seu interesse pelo tema. É indispensável o ensino das regras de Português. Não como algo ditatorial, militar, mas algo que vá acrescentar um novo conhecimento para o aluno. (6per:3res).

O papel de um professor de lingua Portuguesa e estimular o aluno a ter interesse pela própria lingua, trabalhando de maneira interessante e estimulante nas aulas. (6per:9res).

O papel do professor de Língua Português é mostrar ao aluno que o importante ésaber o que dizer, para quem dizer, como dizer e quando dizer, em outras palavras, o importante é saber aplicar o conhecimento nas situaçôes adequadas. (7per:2res).

Orientar os alunos no dominio da língua falada e escrita regida pela norma padrão. Ressaltando que essa orientação deve ser o mais pragmática possivel, de modo a tornar o ensino mais atrativo e aplicável à vivência do aluno, ou seja, contextualizar o ensino da lingua. (8per:15res).

Essas respostas chamam-nos a atenção pelo fato de que, quando se fala da gramática, constata-se a necessidade de se "amenizar" o seu ensino, estabelecendo um contato entre o aluno e a lingua mostrando-a dentro da realidade do aluno: ${ }^{12}$ respeitando os conhecimentos prévios de cada aluno e o meio social que o mesmo está inserido, ${ }^{13}$ enfim, ensinando a língua padrão da forma mais pragmática possivel, de modo a tornar o ensino mais atrativo e aplicável à vivência do aluno, ou seja, contextualizar o ensino da língua. ${ }^{14}$

\footnotetext{
${ }^{12}$ Recorte 1per:3res.

${ }^{13}$ Recorte 4per:8res.

${ }^{14}$ Recorte 8per:15res.
} 
A língua portuguesa representada na figura da gramática é concebida como uma língua que não faz sentido, que não se historiciza para o aluno, pois não faz parte de seu cotidiano (daí a necessidade de ser contextualizada). E, assim sendo, cabe ao professor promover o interesse e a motivação dos alunos, de maneira lúdica, evitando as aulas áridas para não cansar os alunos fazendoos criar aversão pela disciplina ${ }^{15}$ utilizando coisas legais que interessem os alunos como músicas, filmes, teatros ${ }^{16} \mathrm{e}$ métodos pedagógicos apropriados eficazes com o objetivo de que os alunos assimilem o conteúdo de forma prática e agradável. ${ }^{17}$

Sendo o ensino da gramática algo que não traz prazer, que não satisfaz, tenta-se compensar essa falta por meio de uma pedagogia "interessante", dialógica, democrática. Todavia, nota-se, no uso das negativas ("não obrigar", "não impor", "não ditatorial"), o embate com a tradição, com um ensino marcado por um certo autoritarismo, como se pode constatar nos trechos abaixo:

- não assustar o aluno impondo regras e normas. (1 per:59res).

- não impor a disciplina como um obstáculo que tem que ser superado. Se o professor expõe o Português como algo obrigatório, o aluno perde o gosto... (2per:17res).

- sem impor o que é certo ou errado. (4per:11 res).

- levar o idioma para o dia-a-dia do aluno e despertar seu interesse pelo tema. É indispensável o ensino das regras de Português. Não como algo ditatorial, militar, mas algo que vá acrescentar um novo conhecimento para o aluno. (6per:3res).

O ensino da gramática parece, pois, beirar a violência (simbólica?), uma vez que se entende que a negativa aponta justamente para o furo, para a fissura. Diz-se que não se deve impor, porque se impóe; que não se deve assustar, porque se assusta.

Observe-se como o verbo "relutar" reforça esse caráter de violência que permeia o ensino da língua, como se este fosse uma batalha, daí o aparecimento, a nosso ver, de um certo discurso de humanização do ensino, do conteúdo, do professor, como se nota na resposta abaixo:

\footnotetext{
15 Recorte 1per:38res.

16 Recorte 1per:27res.

${ }_{17}$ Recorte 2per:3 res.
} 
Para mim o papel de um Professor de Lingua Portuguesa talvez seja mais de humanizador que de professor de teoria gramatical. Talvez ele devesse ensinar de algum modo tudo que é histórico, cultural e ideológico portanto humano na língua juntamente com o ensino teórico. Porque a lingua na verdade é isto: a história do que pensamos e das palavras e modos de dizer o que pensamos. (8per:16res).

O discurso desse sujeito aponta para o que "deve ser", e que, portanto, não é. Haveria algo de humano na língua, mas não no plano da teoria gramatical. E é curioso pensar na polissemia que o vocábulo "humano" carrega, oferecendo várias possibilidades de leitura. Se, por um lado, ele nos remete ao que é relativo ao homem - colocando, pois, a gramática em outra dimensão (divina? Diabólica?) - por outro, ele também nos remete à ideia de benignidade e compaixão, atributos que parecem não combinar com a gramática. Esta seria impiedosa, cruel, ditatorial. ${ }^{18}$

Esse discurso de humanização parece ser corroborado pela imagem de professor como pai, psicólogo, como aquele que aponta caminhos, que considera o outro (algo que a gramática não faria), que ama, conforme as respostas abaixo:

No que eu pude vivenciar até então é que os professores de Lingua Portuguesa ensinam a gramática normativa, literatura, leitura e produção de texto. Os professores de Lingua Portuguesa são direcionados a passarem o que sabem para que o aluno possa enfrentar o vestibular, esse em meu ver é a função desses professores, ensinar para o aluno enfrentar provas e concursos. Mas também podem passar conhecimento de mundo, mostrar para o aluno os obstáculos que vão enfrentar ao saírem da escola, as dificuldades de vida. (1per:10res).

O papel do professor de Lingua Portuguesa é ensinar os alunos regras da língua, interpretaçôes de textos. É entender e ajudar os alunos e as pessoas entenderem o uso de nossa lingua e demais funçôes relacionadas ao professor. As demais funçôes relacionadas ao professor é educar, ensinar a tratar com respeito os alunos e as pessoas, é debater outros assuntos relacionados com a vida, é conversar com um aluno que esteja passando por problemas ou que esteja com mais dificuldades de aprender que outro aluno. (1 per:29res).

${ }^{18}$ Recorte 6per:3res. 
Além de todas as características citadas na questão anterior, o papel do professor é amar primeiro o que ensina e depois amar a quem ensina e posteriormente passar com amor o que se ensina. Dessa forma, sem dúvida, exercerá um papel importante como professor. (4per:55res).

O professor parece encontrar-se no embate da imagem de língua ora como companheira, ora como vilā, para retomar os termos usados pelo sujeito abaixo:

Creio que o professor de Português deva expor aos seus alunos uma forma de aprendizagem não taxativa, uma maneira de ver a língua como companheira e não como vilä; incentivar a leitura como instância fiadora de conhecimento lingüistico, além de demonstrar aos alunos as múltiplas possibilidades que o idioma oferece tanto para os atos conversacionais quanto para as representaçôes escritas. Ou seja, mostrar aos alunos que existe algo maior que os convencionalismos do idioma. (2per:10res).

Como, entretanto, não mostrar uma língua vilāa, se ela é imposta aos alunos, se parece tão distante de sua realidade, de sua história? Como ela pode ser companheira se não acompanha esse sujeito? Nesse confronto, constata-se que o papel de um professor de língua portuguesa é um dos mais cruéis ${ }^{19}$ possiveis, pois o mesmo terá de passar algo que para a sua platéia não há necessidade alguma em aprender, visto que os mesmos, por falarem a lingua, não vêem necessidade de aprender. ${ }^{20}$

De fato, pode-se dizer que o discurso pedagógico, o qual permeia os cursos de Licenciatura em geral, cria a ilusão da imprescindibilidade do aprendizado do português padrão. Ainda que não haja "motivação", utilidade, interesse dos alunos, afirma-se que o seu ensino é essencial. Basta que haja uma mudança na atitude dos professores ou na metodologia de ensino (o ensino deve ser "consciente") e tudo estará resolvido.

Orlandi (2001b) argumenta que, no discurso pedagógico, as justificativas se restringem ao "é porque é". Isto é, não se explica, de fato, as razões do objeto de estudo ${ }^{21}$ e, como consequência, esse discurso utiliza, em termos da linguagem

\footnotetext{
${ }^{19}$ Interessante o uso do termo cruéis, que aponta também para o efeito de sentido de desumanização da gramática.

${ }^{20}$ Recorte 4per:27res.

${ }^{21}$ Esse seria um dos aspectos, apontados por Orlandi (ibidem), que estaria presente na inculcação feita pelo ato de ensinar, na escola. Os outros seriam a quebra das leis do discurso, enunciadas por Ducrot (1972) e a cientificidade.
} 
sobre o objeto, os dêiticos, a objetalização, a repetição, as perífrases. E, em relação à metalinguagem, usam-se as definições rígidas, os cortes polissêmicos etc.

Nota-se que, apesar de se afirmar que a língua da escola é completamente distinta da usada fora do âmbito escolar, o sujeito insiste em que ela deva ser ensinada. Nesse momento, entra o papel do professor e a imagem que se constrói dele: alguém que deve - e, portanto, não é - ser capaz de estabelecer um diálogo entre o conteúdo da escola e a realidade dos alunos. A culpa do fracasso escolar do aluno passa a recair, então, sobre o professor, assim como a possibilidade de mudança dessa situação. É preciso que esse professor encontre estratégias para motivar o aluno a aprender.

Na verdade, a concretização do "sucesso" desse aluno parece ser sempre adiada. Se o problema antes era a metodologia tradicional de ensino, baseada na mera imposição de uma norma linguística, agora, com posse de uma outra concepção (o ensino "respeitoso" da norma padrão), a culpa está no professor que deve se tornar mais consciente e mudar sua atitude.

A imposição (já que essencial!) de um ensino que está desvinculado da realidade dos alunos parece ser redimida nas aulas "críticas" e "conscientes"; aulas em que o professor respeita os conhecimentos prévios de cada aluno e o meio social que o mesmo está inserido. ${ }^{22}$

Cremos que nessa contradição de ter de aprender uma língua que não se usa entrelaçam-se dizeres de diferentes regiōes interdiscursivas. O dizer do discurso pedagógico, estabelecendo o "é porque é" e a necessidade de conscientização crítica; o dizer das teorias linguísticas que postulam o aprendizado da norma culta como forma de ampliar a competência comunicativa dos alunos com o devido respeito à língua do aluno; o dizer do senso-comum sobre a língua, presente nas consideraçôes de que o ensino da norma culta se justifica por ela ser a "certa".

E, mais do que isso, parece-nos haver mesmo uma relação de amor e ódio para com essa língua, já que, no discurso do sujeito, percebe-se um jogo de aceitação e resistência da gramática normativa. Ao falar do aluno (seus futuros alunos, provavelmente), é de si mesmo que o sujeito fala, projetandose como aquele que ora não via sentido nas "enfadonhas e áridas aulas de português" e que ora gostaria de ter não apenas aprendido essa língua, mas de a ter apreendido, apropriado-se dela, enfim, tornado-se seu senhor.

${ }^{22}$ Recorte 4per:8res. 


\section{Considerações Finais}

Ao responder a pergunta Você acha que seria interessante se fosse incluida, no curso de Letras, a disciplina "Gramática Normativa"? Justifique a sua resposta, os sujeitos constroem a gramática normativa como língua legítima, lugar de totalização do saber sobre a língua e a imagem de professor de português como quem deve "dominar" as regras gramaticais, apontando para uma lacuna, a seu ver, entre a teoria e a prática. O sujeito está em falta, já que confessa não saber gramática (não estando, assim, capacitado para lecionar). E o embate das vozes se marca justamente nesse desejo de "possuir" a GN e na impossibilidade de confessá-lo, senão com ressalvas.

Por outro lado, nas respostas à pergunta Qual o papel de um professor de Lingua Portuguesa?, pode-se observar o embate de vozes trabalhando no sentido de relativizar a imagem de GN como saber legitimado, por meio do discurso pedagógico, que postula a contextualização das regras da gramática, tornando-a mais próxima da realidade do aluno, e a necessidade de se humanizar o ensino (por meio do amor, do respeito, do interesse pelo outro), denunciando, assim, seu caráter impositivo.

As análises apontam para o fato de que o sujeito é afetado pelos dizeres da formação discursiva em que se encontra, e que não há, dessa forma, sentidos aleatórios, originais ou individuais (a não ser como ilusão). Ele carrega - no sentido de que o sujeito é atravessado por um saber e não que "acumula" em si conhecimentos - um saber que lhe é constitutivo e, consequentemente, inapagável.

Vê-se que, ao longo do curso de Letras, no processo de ensinoaprendizagem, o sujeito não abandona um conhecimento para se apropriar de outro, como se esse processo ocorresse de forma linear e contínua. Assim, as vozes se confrontam e trazem à tona, na superfície linguística, o conflito entre saberes provenientes de diferentes regiōes interdiscursivas.

Tais saberes se sobrepõem, se entrecruzam, se imbricam, mas jamais se anulam. Isto é, o saber constitutivo do sujeito, apropriado e construído ao longo de sua vida (de suas histórias de leitura, de suas memórias discursivas) se emaranha a esse "novo" saber, marcando o discurso como lugar de contradição, dispersão e repetição de sentidos.

Há um espaço de interdição para o sujeito-professor-de-língua(s)-emformação. Em outras palavras, agora o sujeito, ao falar sobre a língua, se encontra em um inter-dito, entre dizeres, entre saberes, entre imagens e vozes conflitantes. Ao tentar articular a imagem que ele tem do saber sobre a língua, 
a imagem que a instituição, os especialistas ou a sociedade têm desta, a imagem que ele tem que os outros têm dele enquanto professor de línguas em formação, o sujeito tece seu discurso com fios que não coincidem, com vozes dissonantes, com saberes contraditórios, num jogo mesmo de unidade e dispersão.

Há uma memória da normatividade acerca da língua materna que se mistura, no discurso dos sujeitos, às imagens projetadas do lugar do qual ele enuncia - a posição de sujeito-professor-de-língua(s)-em-formação. Assim, apesar de se mostrar afetado pelo lugar do qual fala, apropriando-se dos dizeres das teorias linguísticas e pedagógicas, os sujeitos ainda consolidam, em seu discurso, relações dicotômicas no que diz respeito à noção de língua e ensino.

Pode-se perceber dicotomização entre os pares norma culta x norma coloquial / regionalismo; unidade x diversidade; língua escrita x língua oral; teoria x prática, sendo, normalmente, apenas um dos pólos privilegiado.

Diante disso, podemos questionar a formação desse professor e indagar até que ponto há deslocamentos em suas concepçōes teóricas ao longo do curso. Não se trata aqui de pensar em soluções para resolver as contradições desse sujeito-professor-de-língua(s)-em-formação, mas de compreender que as fissuras, as tensões são constitutivas dos sujeitos e da linguagem.

Cremos que a possibilidade de deslocamentos discursivos que influenciarão a prática pedagógica desse sujeito passa, primeiramente, pela compreensão da natureza heterogênea da linguagem e do fato de que, como sujeitos da linguagem - e, portanto, cindidos e fragmentados - estamos todos presos na rede de significantes, na porosidade da linguagem, irremediavelmente constituídos por vozes em embate.

\section{Referências}

DUCROT, O. Princípios de semântica lingüistica (dizer e não dizer). São Paulo: Cultrix, 1972.

ORLANDI, Eni Pulccinelli. Discurso e leitura. 6. ed. São Paulo, Cortez, 2001a. $118 \mathrm{p}$.

ORLANDI, Eni Pulccinelli. A linguagem e seu funcionamento: as formas do discurso. 4. ed. Campinas, SP: Pontes, 2001b. 276p.

ORLANDI, Eni Pulccinelli. Interpretação: autoria, leitura e efeitos do trabalho simbólico. 4. ed. Campinas: Pontes, 2004. 156p.

ORLANDI, Eni Pulccinelli. Discurso e texto: formulação e circulação dos sentidos. Campinas, SP: Pontes, 2005a. 218p. 
ORLANDI, Eni Pulccinelli. A Análise de Discurso em suas diferentes tradições intelectuais: o Brasil. In: INDURSKY, F.; FERREIRA, M.C.L. (Org.). Michel Pêcheux e a análise do discurso: uma relação de nunca acabar. São Carlos: Claraluz, 2005b. p. 75-88.

ORLANDI, Eni Pulccinelli. Análise do Discurso: princípios e procedimentos. 6. ed. Campinas, SP: Pontes, 2005c. 100p.

PÊCHEUX, Michel. Semântica e discurso: uma crítica à afirmação do óbvio. 3. ed. Trad. Eni Pucinelli Orlandi [et al.]. Campinas, SP: Editora da UNICAMP, 1997a. 317p.

PÊCHEUX, Michel. Análise automática do discurso. In: GADET, F.; HARK, T. (Org.). Por uma análise automática do discurso: uma introdução à obra de Michel Pêcheux. 3. ed. Trad. Bethania S. Mariani [et al.]. Campinas, SP: Editora da Unicamp, 1997b. p. 61-105.

PÊCHEUX, Michel. Discurso: estrutura ou acontecimento. Trad. Eni Puccinelli Orlandi. 3. ed. Campinas, SP: Editora da Unicamp, 1997c. 68p.

PIETRI, Émerson de. A constituição do discurso da mudança do ensino de língua materna no Brasil. 2003. Tese. (Doutorado em Línguística Aplicada ao Ensino/ Aprendizagem de Língua Materna). Instituto de Estudos da Linguagem, Universidade Estadual de Campinas, Campinas, 2003.

SOARES, M. Português na escola: história de uma disciplina curricular. In: BAGNO, M. (Org.). Linguistica da norma. São Paulo, Loyola: 2002.

Recebido em 03/03/2010. Aprovado em 22/11/2010. 